African Crop Science Journal by African Crop Science Society is licensed under a Creative Commons Attribution 3.0 Uganda License. Based on a work at www.ajol.info/ and www.bioline.org.br/cs DOI: https://dx.doi.org/10.4314/acsj.v28i1.6S

\title{
EVALUATION OF POPULAR CASSAVA VARIETIES FOR YIELD AND CYANIDE CONTENT UNDER ASAL CONDITIONS IN KENYA
}

\author{
M. WAMBUA, R.M.S. MULWA, P.F. ARAMA ${ }^{1}$, S.A. ATIENO ${ }^{1}$ and J.O. OGENDO \\ Egerton University, P. O. Box 536, Egerton-20115, Kenya \\ ${ }^{1}$ Rongo University, P. O. Box 103, Rongo-40404, Kenya \\ Corresponding author: rmulwa@egerton.ac.ke
}

\begin{abstract}
Cassava (Manihot esculenta Crantz) is a staple food crop grown by smallholder farmers in the marginal regions of western, coastal and eastern Kenya. The objective of this study was to evaluate popular cassava varieties for yield and cyanide content in the arid and semi-arid regions of Kenya. The study was carried out at five sites located in three sub-counties of Nakuru county in Kenya. Treatments included a collection of 27 sweet cassava varieties obtained from Western Kenya. Results revealed significant variations among varieties in all sites, for all parameters measured. The highest yields were obtained at Subukia, with the variety MM99/0067 yielding up to $200 \mathrm{t} \mathrm{ha}^{-1}$. Cyanide content varied significant among the varieties and sites; and was high in most of the cultivars, with highest levels recorded in variety Rao Onyoni $\left(17.3 \mathrm{mg} 100 \mathrm{~g}^{-1}\right)$ grown at the Lare site. The highest dry matter content was recorded in variety Selele rabuor $(60.5 \%)$, at the Solai III site. Participating farmers ranked the materials based on yield, taste and order of general preference as follows: Subukia site (MM96/0067, NyaTanga, Adhiambo Lera, KME-1 and MH95/0183); Lare site (Nyar AICAD, Nyar Maseno, NyaTanga, and MM96/2480); and Solai site (KME-1, Nyar AICAD, Adhiambo Lera, Karembo, and Obaro dak).
\end{abstract}

Key Words: Cyanide, dry matter, Manihot esculenta, starch

\section{RÉSUMÉ}

Le manioc (Manihot esculenta Crantz) est une culture vivrière de base cultivée par les petits agriculteurs dans les régions marginales de l'Ouest, de Littoral et de l'Est du Kenya. L'objectif de cette étude était d'évaluer les variétés de manioc populaires pour le rendement et la teneur en cyanure dans les régions arides et semi-arides du Kenya. L'étude a été réalisée sur cinq sites situés dans trois sub-counties de Nakuru county in Kenya au Kenya. Les traitements comprenaient une collection de 27 variétés de manioc sucré obtenues dans l'Ouest du Kenya. Les résultats ont révélé des variations importantes entre les variétés dans tous les sites, pour tous les paramètres mesurés. Les rendements les plus élevés ont été obtenus à Subukia, la variété MM99 / 0067 produisant jusqu'à 200 t ha ${ }^{-1}$. La teneur en cyanure variait considérablement selon les variétés et les sites; et il était élevé dans la plupart des cultivars, avec des niveaux plus élevés enregistrés dans la variété Rao Onyoni (17,3 mg $\left.100 \mathrm{~g}^{-1}\right)$ cultivée sur le site de Lare. La teneur en matière sèche la plus élevée a été enregistrée chez la variété 
Selele rabuor (60,5\%), sur le site de Solai III. Les agriculteurs participants ont classé les matériaux en fonction du rendement, du goût et de l'ordre de préférence générale comme suit: Site de Subukia (MM96 / 0067, NyaTanga, Adhiambo Lera, KME-1 et MH95 / 0183); Site Lare (Nyar AICAD, Nyar Maseno, NyaTanga et MM96 / 2480); et le site de Solai (KME-1, Nyar AICAD, Adhiambo Lera, Karembo et Obaro dak).

Mots Clés: Cyanure, matière sèche, Manihot esculenta, amidon

\section{INTRODUCTION}

Cassava (Manihot esculenta Crantz) is a food crop grown by smallholder farmers in the marginal regions of western, coastal and eastern Kenya. Cassava is consumed in fresh and processed forms; as part of diets in breakfast, lunch and/or dinner or in the form of snacks. Production and consumption, however, sharply declined in the 1990s due to outbreaks of Cassava Mosaic Disease (CMD) and Cassava Brown Streak Diseases (CBSD). Consumption of cassava is now being encouraged, following the realisation that it can relieve demand pressure on cereals in human diets, animal feeds, and some industrial products in the face of a changing and variable climate, because it is drought tolerant.

Development of the food, industrial and adaptation roles of cassava has attracted targeted interventions, with the Government of Kenya investing in improving production, research, marketing and regulations to develop the cassava industry, even in other suitable nontraditional regions. The arid and semi-arid areas of Nakuru county exemplify suchnontraditional, where the Government of Kenya introduced cassava production and agribusiness promotion to ameliorate effects of recurrent droughts and maize crop failures. In this effort, five varieties were introduced and enabled to raise the overall cassava production in the area from 500 tonnes in $2010 / 11$ to over 3000 tonnes by 2014/15, with 1700 smallholder farmers getting involved (World Bank, 2018). This scaling occurred in the period when farmers were searching for alternative adaptable crops to maize, which was massively failing due to Maize Lethal Necrosis disease and recurrent droughts.

Though the introduced cassava varieties had good yields of 10 to $20 \mathrm{~kg}$ per mature plant, their maturity periods were long (18 to 24 months) and turned off most farmers who preferre dearly maturing varieties. In a stakeholder forum conducted by the Egerton University scientists in 2018, the barriers to further scaling up of cassava agribusiness enterprises in Nakuru County were identified as: (i) long maturity periods of varieties, (ii) cassava diseases (CMD and CBSD), (iii) limited variety diversity, (iv) limited consumption options to fresh boiled cassava, and limited value addition technologies, and (v) weak farmer institutions to support cassava value chain upgrading. Another overriding constraint for wide spread cassava adoption in Nakuru county was lack of education on food safety on the crop, with many rural dwellers believing the crop was poisonous (World Bank, 2018).

In light of the above, a community action research project (CARP) dubbed Cassava $\mathrm{CARP}+$ was instituted, aimed at mobilising communities in the arid and semi-arid lands (ASALs) of Nakuru county to adopt cassava production through a farmer participatory approach, by introducing early maturing varieties (12-14 months) and capacity building to ensure that individual farmers and farmer groups produce value added products from cassava. In the project, youths from Technical and Vocational Education (TVET) institutions were also trained as service providers to cassava farmers. The objective of the present study was to evaluate popular cassava varieties 
for yield and cyanide content in the arid and semi-arid regions of Kenya.

\section{MATERIALS AND METHODS}

Study site. This study was carried out in three sub-counties (Rongai, Subukia and Njoro) of Nakuru County in Kenya. The specific sites were five farmers' fields located in Solai (Rongai; 3 diverse fields), Lower Subukia (Subukia; one field) and Lare (Njoro; one field). These sites were selected because they are known arid and semi-arid pockets within the high potential Nakuru County, and have diverse soil types (Jaetzold et al., 2010). The farmer hosts for the trials at the Rongai and Subukia sites were selected through a nomination process by farmer groups within the areas, guided by the resident field agricultural officers. The farmers picked had previously participated in cassava introduction efforts, as lead farmers. For each farmer's field selected, there were 40-50 surrounding farmers who would access the site for training and crop evaluations. The Lare site was selected since it hosted a training centre, where farmers from Njoro sub-county participated in technology transfer activities. Trainings targeted cassava farmers at the site registered a regular attendance of around 92 farmers.

Treatments and design. The study was conducted with 27 cassava landraces and varieties collected from various growing sites in western and coastal regions of Kenya; namely, Migori, Busia, Kakamega, Kisumu and Kilifi (Table 1). In each of the farmers' field, the varieties constituted the treatments and were planted in a randomised complete block design (RCBD), with three replications. Cuttings of $25 \mathrm{~cm}$ length were randomly assigned to the plots and planted at a spacing of $1 \mathrm{~m} \times 1 \mathrm{~m}$, in plots measuring $4 \mathrm{~m} \times 2 \mathrm{~m}$. There were three rows of plants in each plot; each row with five plants for a total of 15 plants per plot. Regular inspection to assess readiness for harvesting commenced nine months after planting and the first harvesting was started at 12 months for the earliest varieties and ended at 14 months. At each harvest, cassava plants were carefully uprooted, ensuring that all roots were recovered intact for subsequent data collection.

\section{Data collection}

Root yield. The total number of roots and number of normal and marketable roots were counted from the three middle plants harvested in each plot. The weight of the marketable roots was determined using a sensitive portable electronic scale (WeiHeng, China). Sample roots of approximately $3 \mathrm{~kg}$ were packaged in shopping bags and transported to the laboratory for further processing and analyses.

Food safety assessment. At harvest, a field sensory evaluation was conducted by farmers for the freshly harvested cassava, by sectioning $4 \mathrm{~mm}$ slices at the middle of a randomly selected prime root from each harvested plant in a plot. Nine farmers were engaged in tasting the peeled slices from each plant and give a rank of 1 for sweet taste or 2 for bitter taste as described in the Fukuda $e t$ al. (1998) manual. For each cassava variety, a rank of 1 or 2 was assigned where five or more of the tasters gave the same rank.

In the laboratory, further determination of cyanide content from the sampled roots was done using the alkaline titration method (Association of Official Analytical Chemists (AOAC) Methods, 1990). Ten grammes of grated fresh cassava was taken and transferred into distillation tubes. One hundred $\mathrm{ml}$ of distilled water was added and the mixtures left to settle for 2 hours. Twenty-five millilitres of $2.5 \%$ sodium hydroxide $(\mathrm{NaOH})$ was placed into a conical flask connected to a distillation unit. The distillation tubes bearing the samples were also connected to the unit and the distillation ran until $70 \mathrm{ml}$ of distillate was obtained. Eight millilitres of 5\% potassium 
TABLE 1. Cassava varieties tested ASAL regionand their sources in Kenya

\begin{tabular}{|c|c|c|}
\hline Entry & Variety & Source \\
\hline 1 & MH95/0183 & Tropical Manioc Selection (TMS), from a farmer in Busia County \\
\hline 2 & MM96/0013 & Tropical Manioc Selection (TMS), from a farmer in Busia County \\
\hline 3 & MM98/0011 & Tropical Manioc Selection (TMS), from a farmer in Busia County \\
\hline 4 & MM98/3567 & Tropical Manioc Selection (TMS), from a farmer in Busia County \\
\hline 5 & MM96/7680 & Tropical Manioc Selection (TMS), from a farmer in Busia County \\
\hline 6 & MM96/2480 & Tropical Manioc Selection (TMS), from a farmer in Busia County \\
\hline 7 & KME-1 & $\begin{array}{l}\text { TMS, Kenya Agricultural and Livestock Research Organization } \\
\text { (KALRO) Research Centre, Njoro }\end{array}$ \\
\hline 8 & MM96/1871 & $\begin{array}{l}\text { TMS, Kenya Agricultural and Livestock Research Organization } \\
\text { (KALRO) Research Centre, Njoro }\end{array}$ \\
\hline 9 & MM99/0067 & $\begin{array}{l}\text { TMS, Kenya Agricultural and Livestock Research Organization } \\
\text { (KALRO) Research Centre, Njoro }\end{array}$ \\
\hline 10 & MM99/0072 & $\begin{array}{l}\text { TMS, Kenya Agricultural and Livestock Research Organization } \\
\text { (KALRO) Research Centre, Njoro }\end{array}$ \\
\hline 11 & Migyera & $\begin{array}{l}\text { TMS, Kenya Agricultural and Livestock Research Organization } \\
\text { (KALRO) Research Centre, Njoro }\end{array}$ \\
\hline 12 & MM99/4884 & $\begin{array}{l}\text { TMS, Kenya Agricultural and Livestock Research Organization } \\
\text { (KALRO) Research Centre, Njoro }\end{array}$ \\
\hline 13 & Adhiambo Lera & Local landrace, farmer Migori County \\
\hline 14 & Nyar AICAD & Local landrace, farmer Migori County \\
\hline 15 & Nyar JICA & Local landrace, farmer Migori County \\
\hline 16 & Mabul & Local landrace, farmer Migori County \\
\hline 17 & Okonyo Welo & Local landrace, farmer Migori County \\
\hline 18 & Madam & Local landrace, farmer Migori County \\
\hline 19 & Masisa & Local landrace, farmer Migori County \\
\hline 20 & Nyar Maseno & Local landrace, farmer Kisumu County \\
\hline 21 & NyaTanga & Local landrace, farmer Migori County \\
\hline 22 & Obaro Dak & Local landrace, farmer Migori County \\
\hline 23 & Oduwo & Local landrace, farmer Migori County \\
\hline 24 & Olomba & Local landrace, farmer Migori County \\
\hline 25 & Rao Onyoni & Local landrace, farmer Migori County \\
\hline 26 & Selele rabuor & Local landrace, farmer Migori County \\
\hline 27 & Karembo & Local landrace, farmer Kilifi County \\
\hline
\end{tabular}

iodide (KI) was added to each distillate sample and titrated using $0.02 \mathrm{M}$ silver nitrate $\left(\mathrm{AgNO}_{3}\right)$, with the end point marked by the appearance of a light blue colour. The titrated cyanide content was computed as follows:

$\mathrm{Mg} / 100 \mathrm{~g} \mathrm{HCN}=\frac{\text { Titre } \times 108}{\text { sample weight }}$

Where:
$1 \mathrm{ml}$ of $\mathrm{AgNO}_{3}=1.08 \mathrm{mg} \mathrm{HCN}$

Dry matter content. Dry matter content was determined using the oven drying method on a moisture content basis according to the AOAC Methods (2006). Cassava roots were peeled and grated using a hand held grater. Two grammes of the grated cassava material was taken into aluminium moisture 
determination dishes and oven-dried at $105^{\circ} \mathrm{C}$, until a constant weight was recorded. The percentage dry matter content was computed using the formula below:

$\mathrm{DM} \%=\frac{\mathrm{W}_{2-} \mathrm{W}_{3}}{\mathrm{~W}_{1}} \times 100$

Where:

$\mathrm{DM} \%=$ percentage dry matter; $\mathrm{W}_{1}=$ weight of the wet sample; $\mathrm{W}_{2}=$ weight of dry sample plus the dish; and $\mathrm{W}_{3}=$ weight of the empty dish.

Data analysis. A generalised Linear Model of SAS Statistical Software package was used to conduct analysis of variance on the data collected. Data from each site were analysed separately to be able to determine best performing varieties for each site on the basis of high yields, high dry matter and low cyanogenic potential based on the sensory and chemical analysis. Analyses for dry cyanide and matter contents were conducted in triplicates and data pooled from each sampled plot to compute means.

Selection of varieties for the test locations. In each of the three sub-counties, groups of ten representative farmers were asked to make simple consensus ranked selections of their five best yielding and safe (not bitter) varieties for further bulking and distribution in their localities. The criteria set for yield was a minimum of $30 \mathrm{tha}^{-1}$.

\section{RESULTS AND DISCUSSION}

Tuber yield. The number of commercial tubers per plant varied significantly among the cultivars at each site (Table 2). The highest numbers of tubers were recorded from varieties NyaTanga (15.7), Karembo (15) and MM99/0067 (14.3) at Subukia; while the lowest number of commercial tubers was obtained in variety Migyera (1.7) in the Solai I site.

Highly significant variations were observed in yields of the 27 varieties of cassava evaluated (Table 2). Although all the varieties grew and produced yields in one site (Solai II), some varieties totally failed in the other four sites (Table 2). Six varieties (MH95/0183, MM96/0013, MM96/2480, MM96/7680, MM98/0011 and MM98/3567) failed at Solia I site, five at Solai III site (MH95/0183, MM96/ 0013, MM96/7680, MM98/0011 and MM98/ 3567) and one each at the Lare (Olomba) and Subukia (Oduwo) sites. The failure at each site was depicted as gross non-performance, where the varieties did not produce any crop. Variation in performance was expected due to the different adaptations of the germplasm set under testing. This is also a basis for selection of germplasm for a specific site for maximising productivity. Dixon et al. (1991) reported that although cassava is a widely adaptable crop, some individual varieties are limited in performance because of the crop's sensitivity to genotype by environment (GxE) interactions. Hence, to maximise productivity of particular genotypes, they must be grown in the adaptable environments. Testing cultivars across diverse soil and other environmental conditions could assist in selecting varieties with general and specific adaptabilities.

On yield basis, there were highly significant variations in yield potentials expressed by the varieties at each site (Table 2). In general, the highest yield responses were recorded at the Subukia site where the yield ranged from 17.67 (var. MM98/3567) to 200 (var. MM99/0067) tonnes per hectare (Table 2). At this site, out of the 27 varieties tested, 23 produced yields above 30 tonnes per hectare, indicating a highly suitable environment for maximising cassava yield. These yields were way above the global reported average yields of 23.2 tonnes of roots per hectare (Food and Agriculture Organisation of the United Nations (FAO), 2013). But FAO (2013) also estimate the potential yield of cassava to be more than 80 tonnes per hectare 
TABLE 2. Number of commercial roots and yield of 27 cassava varieties grown in Nakuru county, Kenya

\begin{tabular}{|c|c|c|c|c|c|c|c|c|c|c|}
\hline \multirow[t]{3}{*}{ Variety } & \multicolumn{10}{|c|}{ Sites } \\
\hline & \multicolumn{2}{|c|}{ Solai I } & \multicolumn{2}{|c|}{ Solai II } & \multicolumn{2}{|c|}{ Solai III } & \multicolumn{2}{|c|}{ Lare } & \multicolumn{2}{|c|}{ Lower Subukia } \\
\hline & $\begin{array}{c}\text { Number of } \\
\text { tubers }\end{array}$ & $\begin{array}{l}\text { Yield } \\
\left(\mathrm{t} \mathrm{ha}^{-1}\right)\end{array}$ & $\begin{array}{c}\text { Number of } \\
\text { tubers }\end{array}$ & $\begin{array}{l}\text { Yield } \\
\left(\mathrm{t} \mathrm{ha}^{-1}\right)\end{array}$ & $\begin{array}{c}\text { Number of } \\
\text { tubers }\end{array}$ & $\begin{array}{l}\text { Yield } \\
\left(\mathrm{t} \mathrm{ha}^{-1}\right)\end{array}$ & $\begin{array}{c}\text { Number of } \\
\text { tubers }\end{array}$ & $\begin{array}{l}\text { Yield } \\
\left(\mathrm{t} \mathrm{ha}^{-1}\right)\end{array}$ & $\begin{array}{c}\text { Number of } \\
\text { tubers }\end{array}$ & $\begin{array}{l}\text { Yield } \\
\left(\mathrm{t} \mathrm{ha}^{-1}\right)\end{array}$ \\
\hline Adhiambo Lera & 4 & 15.63 & 4.33 & 25.53 & 6.33 & 60.33 & 5.67 & 16.2 & 10.0 & 120.0 \\
\hline Karembo & 5 & 25.13 & 4.33 & 27.37 & 6.67 & 60.33 & 8.0 & 28.33 & 15.0 & 180.0 \\
\hline KME-1 & 6.3 & 27.27 & 8.0 & 84.43 & 7.67 & 82.67 & 6.0 & 26.93 & 10.33 & 111.2 \\
\hline Mabul & 6 & 18.13 & 6.0 & 31.23 & 5.33 & 45.73 & 7.33 & 21.9 & 4.33 & 45.0 \\
\hline Madam & 7 & 26.50 & 2.33 & 10.83 & 6.33 & 41.5 & 4.33 & 10.53 & 5.0 & 70.0 \\
\hline Masisa & 7.67 & 19.03 & 5.33 & 25.3 & 5.33 & 55.8 & 9.0 & 33.2 & 8.0 & 80.0 \\
\hline Migyera & 1.67 & 6.93 & 4.0 & 16.13 & 7.67 & 34.1 & 7.33 & 17.97 & 3.67 & 43.33 \\
\hline MH95/0183 & 0.0 & 0.0 & 4.33 & 25.03 & 0.0 & 0.0 & 4.33 & 25.2 & 6.33 & 63.2 \\
\hline MM96/0013 & 0.0 & 0.0 & 7.33 & 26.27 & 0.0 & 0.0 & 7.66 & 19.9 & 6.67 & 53.33 \\
\hline MM96/1871 & 7.67 & 22.2 & 7.67 & 43.53 & 8.0 & 49.97 & 6.33 & 19.8 & 7.67 & 70.0 \\
\hline MM96/2480 & 0.0 & 0.0 & 5.67 & 23.57 & 9.33 & 29.87 & 7.67 & 26.8 & 8.33 & 58.17 \\
\hline MM96/7680 & 0.0 & 0.0 & 5.67 & 25.4 & 0.0 & 0.0 & 9.0 & 26.2 & 4.33 & 25.3 \\
\hline MM98/0011 & 0.0 & 0.0 & 4.67 & 21.93 & 0.0 & 0.0 & 5.0 & 7.73 & 7.33 & 44.97 \\
\hline MM98/3567 & 0.0 & 0.0 & 3.33 & 14.8 & 0.0 & 0.0 & 9.0 & 34.3 & 4.0 & 17.67 \\
\hline MM99/0067 & 5.33 & 21.63 & 4.67 & 23.07 & 5.33 & 25.6 & 4.33 & 9.4 & 14.33 & 200.0 \\
\hline MM99/0072 & 5.33 & 25.7 & 4.33 & 22.47 & 8.33 & 46.71 & 4.33 & 16.8 & 7.67 & 91.0 \\
\hline MM99/4884 & 4.67 & 19.23 & 6.33 & 34.2 & 6.33 & 60.2 & 5.67 & 21.87 & 5.33 & 41.67 \\
\hline Nyar AICAD & 5.33 & 19.9 & 5.33 & 24.97 & 11.33 & 89.4 & 9.0 & 45.57 & 14.33 & 160.0 \\
\hline Nyar JICA & 4.0 & 20.9 & 3.33 & 12.93 & 5.67 & 59.2 & 6.33 & 31.77 & 4.67 & 75.0 \\
\hline Nyar Maseno & 3.33 & 22.0 & 7.33 & 38.33 & 8.67 & 66.0 & 8.0 & 45.3 & 9.0 & 105.0 \\
\hline NyaTanga & 5.33 & 19.6 & 2.0 & 10.0 & 7.33 & 71.8 & 6.33 & 35.6 & 15.67 & 195.0 \\
\hline ObaroDak & 5.0 & 27.2 & 8.0 & 37.6 & 7.0 & 45.9 & 5.33 & 16.47 & 6.0 & 55.0 \\
\hline Oduwo & 4.67 & 11.97 & 2.67 & 12.8 & 7.0 & 37.37 & 4.67 & 9.47 & 0.0 & 0.0 \\
\hline Okonyo Welo & 8.33 & 36.5 & 4.0 & 18.23 & 10.0 & 79.13 & 5.67 & 12.6 & 11.33 & 90.0 \\
\hline Olomba & 4.33 & 19.13 & 5.0 & 21.67 & 8.33 & 49.9 & 0.0 & 0.0 & 5.67 & 55.0 \\
\hline Rao Onyoni & 6.0 & 19.17 & 5.33 & 19.47 & 7.67 & 46.5 & 6.67 & 11.37 & 5.33 & 30.0 \\
\hline Selele Rabuor & 6.67 & 16.07 & 6.67 & 27.17 & 5.67 & 30.57 & 2.67 & 8.07 & 8.33 & 55.0 \\
\hline $\operatorname{LSD}(0.05)$ & 5.43 & 16.97 & 6.38 & 32.33 & 9.8 & 73.22 & 6.23 & 28.06 & 6.32 & 83.29 \\
\hline
\end{tabular}


with improved crop and soil management, and the use of improved higher yielding varieties.

The top three varieties at each site were different (Table 2). At Subukia, MM99/0067, NyaTanga, and Karembo were the best performing varieties with yields of 200, 195 and 180 tonnes per hectare, respectively. At the Solai III, Nyar AICAD, KME-1 and Okonyo welo topped with yields of $89.4,82.7$ and 79 tonnes, respectively. Varieties KME-1, MM96/ 1871 and Nyar Maseno were the best with yields of $83.4,43.5$ and 38.3 tha $^{-1}$, respectively at the Solai II site. At the Lare site Nyar AICAD (45.6 $\mathrm{t} \mathrm{ha}^{-1}$ ), Nyar Maseno (45.3 $\mathrm{t} \mathrm{ha}^{-1}$ ) and NyaTanga (35.6 tha-1) were the best.

With the above observations, a minimum of $30 \mathrm{t} \mathrm{ha}^{-1}$ selection basis would be set, indicating that only one variety (Okonyo welo, $36.5 \mathrm{t} \mathrm{ha}^{-1}$ ) was selectable at the Solai I site. Based on this, we conclude that there is potential for high cassava productivity at Subukia, Solai II and III and Lare sites; farmers in these locations need to be encouraged to take up the crop to ameliorate the effects of climatic variabilities and the risk of maize and other annual crop failures, as cassava is more resilient to withstand erratic precipitation regimes (Srihawong et al., 2015).

Cyanide content. There were significant inter- and intra-site differences among the cultivars in terms of titrated cyanide content at each site (Table 3). A wide variation in the concentration of cyanogens is known to exist among different cultivars of cassava (Cardoso et al., 2005; Centro Internacional de agricultura Tropical (CIAT), 2007). Our observations of wide variations of cyanide content in cassava, even for the same varieties grown in different environments, concur with the reports from Raji et al. (2007) and CIAT (2007), showing that different varieties of cassava have varying cyanide contents, and this quantity is affected by climatic conditions and other factors. In the current study, there were no observable trends in the levels of cyanide recorded from the cultivars in the sites; neither was there a site specific association for high cyanide in a particular variety. This inconsistency within samples of the same variety at different sites is testimony that cyanide levels in one sampled site cannot be used as a standard for samples of the same variety collected from a different site. Hence, the same variety can exist in both sweet and bitter forms due to factors that affect cyanide, levels in cassava in a particular location including water stress (Bokanga, 1994; Gitebo et al., 2009) and soil type (CIAT, 1989; Chu, 2015).

Overall, most of the cultivars tested in this study, even though classified as sweet in their collection origins, registered high cyanide levels compared to the maximum allowable limit of $10 \mathrm{mg} \mathrm{kg}^{-1}$ (FAO, 2007), and may be toxic if consumed fresh in large quantities. It has been long reported that the lethal dose for cyanide poisoning is $1 \mathrm{mg} \mathrm{kg}^{-1}$ of live body weight (Oke, 1969). These results are consistent with the assertions that there are no cyanide free cassava varieties (Bradbury and Holloway, 1988). Hence, direct consumption of cassava containing cyanide levels above $10 \mathrm{mg} \mathrm{kg}^{-1}$ is not advisable, unless appropriate measures are undertaken to deplete the cyanide (Ndung'u et al., 2012).

The frequent lack of correlation between sensory evaluation scores and titrated cyanide levels obtained from the different varieties in the different sites (Table 4), tends to confirm the above observation. Cases where varieties known to be sweet have been found to have high cyanide levels also abound, hence, excluding them from the sweet category (CIAT, 1989; Tan, 1995). Some cases in point from the present study were varieties Karembo, Nyar AICAD, MM99/0067 MM96/1871, MM99/4884 and Olomba that recorded high titrated cyanide levels, but received the sweet category rank on sensory tasting. In the same vain, Karembo and MM96/1871 varieties at the Subukia site were ranked as bitter during sensory evaluation, but recorded very low cyanide levels upon biochemical analysis. 
TABLE 3. Cyanide content from fresh cassava from the 27 tested varieties grown in Nakuru county, Kenya

\begin{tabular}{|c|c|c|c|c|c|c|c|c|c|c|}
\hline \multirow[t]{3}{*}{ Variety } & \multicolumn{10}{|c|}{ Sites } \\
\hline & \multicolumn{2}{|c|}{ Solai I } & \multicolumn{2}{|c|}{ Solai II } & \multicolumn{2}{|c|}{ Solai III } & \multicolumn{2}{|c|}{ Lare } & \multicolumn{2}{|c|}{ Lower Subukia } \\
\hline & $\begin{array}{c}\text { Titrated } \\
\text { cyanide } \\
\text { content } \\
\left(\mathrm{mg} 100 \mathrm{~g}^{-1}\right)\end{array}$ & $\begin{array}{c}\text { Sensory } \\
\text { rank }\end{array}$ & $\begin{array}{l}\text { Titrated } \\
\text { cyanide } \\
\text { content } \\
\left(\mathrm{mg} 100 \mathrm{~g}^{-1}\right)\end{array}$ & $\begin{array}{c}\text { Sensory } \\
\text { rank }\end{array}$ & $\begin{array}{c}\text { Titrated } \\
\text { cyanide } \\
\text { content } \\
\left(\mathrm{mg} 100 \mathrm{~g}^{-1}\right)\end{array}$ & $\begin{array}{c}\text { Sensory } \\
\text { rank }\end{array}$ & $\begin{array}{l}\text { Titrated } \\
\text { cyanide } \\
\text { content } \\
\left(\mathrm{mg} 100 \mathrm{~g}^{-1}\right)\end{array}$ & $\begin{array}{c}\text { Sensory } \\
\text { rank }\end{array}$ & $\begin{array}{l}\text { Titrated } \\
\text { cyanide } \\
\text { content } \\
\left(\mathrm{mg} 100 \mathrm{~g}^{-1}\right)\end{array}$ & $\begin{array}{c}\text { Sensory } \\
\text { rank }\end{array}$ \\
\hline Adhiambo Lera & 1.08 & 1 & 9.11 & 1 & 6.14 & 1 & 8.59 & 1 & 6.12 & 1 \\
\hline Karembo & 9.3 & 1 & 3.96 & 1 & 10.59 & 1 & 16.79 & 1 & 6.84 & 2 \\
\hline KME-1 & 1.08 & 1 & 1.08 & 1 & 5.98 & 1 & 4.17 & 1 & 6.84 & 1 \\
\hline Mabul & 9.36 & 1 & 5.04 & 1 & 9.65 & 1 & 1.78 & 1 & 5.76 & 1 \\
\hline Madam & 5.05 & 1 & 4.68 & 1 & 6.77 & 1 & 5.77 & 1 & 7.56 & 1 \\
\hline Masisa & 5.45 & 2 & 5.4 & 1 & 7.47 & 1 & 7.12 & 1 & 7.92 & 2 \\
\hline Migyera & 3.6 & 1 & 8.23 & 1 & 1.61 & 1 & 15.4 & 1 & 6.12 & 2 \\
\hline MH95/0183 & 0.0 & - & 11.27 & 1 & 0.0 & - & 14.15 & 1 & 7.92 & 1 \\
\hline MM96/0013 & 0.0 & - & 4.67 & 1 & 0.0 & - & 2.02 & 1 & 6.48 & 1 \\
\hline MM96/1871 & 7.2 & 2 & 5.76 & 1 & 7.47 & 1 & 15.52 & 1 & 6.84 & 2 \\
\hline MM96/2480 & 0.0 & - & 5.74 & 1 & 6.03 & 1 & 5.01 & 1 & 6.12 & 1 \\
\hline MM96/7680 & 0.0 & - & 6.88 & 1 & 0.0 & - & 7.08 & 1 & 7.2 & 1 \\
\hline MM98/0011 & 0.0 & - & 6.45 & 1 & 0.0 & - & 5.35 & 1 & 7.5 & 1 \\
\hline MM98/3567 & 0.0 & - & 3.69 & 1 & 0.0 & - & 5.74 & 1 & 8.64 & 1 \\
\hline MM99/0067 & 11.52 & 2 & 5.4 & 1 & 4.26 & 1 & 9.69 & 1 & 5.76 & 1 \\
\hline MM99/0072 & 5.4 & 1 & 5.01 & 1 & 3.21 & 1 & 13.46 & 1 & 5.76 & 1 \\
\hline MM99/4884 & 11.88 & 1 & 10.73 & 1 & 6.02 & 1 & 12.71 & 1 & 6.12 & 1 \\
\hline Nyar AICAD & 13.68 & 1 & 1.8 & 1 & 10.62 & 1 & 6.81 & 1 & 6.84 & 2 \\
\hline Nyar JICA & 10.57 & 2 & 5.31 & 1 & 7.88 & 1 & 8.77 & 1 & 6.48 & 1 \\
\hline Nyar Maseno & 13.68 & 2 & 9.72 & 1 & 6.32 & 1 & 5.23 & 1 & 5.4 & 1 \\
\hline NyaTanga & 11.16 & 1 & 10.8 & 1 & 7.85 & 1 & 8.22 & 1 & 6.84 & 1 \\
\hline
\end{tabular}


TABLE 3. Contd.

\begin{tabular}{|c|c|c|c|c|c|c|c|c|c|c|}
\hline \multirow[t]{3}{*}{ Variety } & \multicolumn{10}{|c|}{ Sites } \\
\hline & \multicolumn{2}{|c|}{ Solai I } & \multicolumn{2}{|c|}{ Solai II } & \multicolumn{2}{|c|}{ Solai III } & \multicolumn{2}{|c|}{ Lare } & \multicolumn{2}{|c|}{ Lower Subukia } \\
\hline & $\begin{array}{l}\text { Titrated } \\
\text { cyanide } \\
\text { content } \\
\left(\mathrm{mg} 100 \mathrm{~g}^{-1}\right)\end{array}$ & $\begin{array}{c}\text { Sensory } \\
\text { rank }\end{array}$ & $\begin{array}{c}\text { Titrated } \\
\text { cyanide } \\
\text { content } \\
\left(\mathrm{mg} 100 \mathrm{~g}^{-1}\right)\end{array}$ & $\begin{array}{c}\text { Sensory } \\
\text { rank }\end{array}$ & $\begin{array}{c}\text { Titrated } \\
\text { cyanide } \\
\text { content } \\
\left(\mathrm{mg} 100 \mathrm{~g}^{-1}\right)\end{array}$ & $\begin{array}{l}\text { Sensory } \\
\text { rank }\end{array}$ & $\begin{array}{l}\text { Titrated } \\
\text { cyanide } \\
\text { content } \\
\left(\mathrm{mg} 100 \mathrm{~g}^{-1}\right)\end{array}$ & $\begin{array}{c}\text { Sensory } \\
\text { rank }\end{array}$ & $\begin{array}{l}\text { Titrated } \\
\text { cyanide } \\
\text { content } \\
\left(\mathrm{mg} 100 \mathrm{~g}^{-1}\right)\end{array}$ & $\begin{array}{c}\text { Sensory } \\
\text { rank }\end{array}$ \\
\hline ObaroDak & 9.36 & 1 & 8.53 & 1 & 8.49 & 1 & 8.41 & 1 & 6.12 & 1 \\
\hline Oduwo & 3.6 & 2 & 7.11 & 1 & 5.66 & 1 & 5.94 & 1 & - & - \\
\hline Okonyo Wello & 8.28 & 1 & 8.91 & 1 & 4.23 & 1 & 16.59 & 1 & 5.76 & 1 \\
\hline Olomba & 10.8 & 2 & 8.61 & 1 & 6.27 & 1 & - & - & 6.84 & 1 \\
\hline Rao Onyoni & 3.96 & 1 & 7.92 & 1 & 3.19 & 1 & 17.3 & 2 & 6.12 & 1 \\
\hline Selele Rabuor & 8.36 & 2 & 1.44 & 1 & 8.24 & 1 & 7.31 & 1 & 5.76 & 1 \\
\hline $\operatorname{LSD}(0.05)$ & 4.56 & & 4.36 & & 6.73 & & 6.76 & & 2.78 & \\
\hline \multicolumn{11}{|c|}{$\begin{array}{l}\text { The (-) in the columns represent no data for those varieties for the respective parameter since those varieties failed to produce recordable yields in the } \\
\text { evaluation at respective sites }\end{array}$} \\
\hline
\end{tabular}


TABLE 4. Dry matter content (\%) of 27 varieties of cassava grown in Nakuru county, Kenya

\begin{tabular}{|c|c|c|c|c|c|}
\hline \multirow[t]{2}{*}{ Variety } & \multicolumn{5}{|c|}{ Site } \\
\hline & Solai I & Solai II & Solai III & Lare & Lower Subukia \\
\hline Adhiambo Lera & 43.84 & 42.51 & 53.96 & 40.67 & 32.61 \\
\hline Karembo & 53.97 & 46.12 & 57.35 & 51.59 & 40.01 \\
\hline KME-1 & 37.61 & 43.13 & 50.2 & 53.32 & 37.68 \\
\hline Mabul & 43.76 & 47.14 & 56.01 & 52.15 & 38.46 \\
\hline Madam & 54.28 & 45.89 & 45.69 & 42.71 & 42.8 \\
\hline Masisa & 38.31 & 44.04 & 60.19 & 51.81 & 33.97 \\
\hline Migyera & 46.49 & 45.54 & 44.28 & 52.49 & 36.78 \\
\hline MH95/0183 & - & 41.59 & - & 50.63 & 33.08 \\
\hline MM96/0013 & - & 45.73 & - & 55.19 & 26.12 \\
\hline MM96/1871 & 45.83 & 43.72 & 53.52 & 40.57 & 35.64 \\
\hline MM96/2480 & - & 44.42 & 52.06 & 50.83 & 40.9 \\
\hline MM96/7680 & - & 42.36 & - & 51.39 & 38.33 \\
\hline MM98/0011 & - & 44.36 & - & 43.44 & 39.5 \\
\hline MM98/3567 & - & 40.91 & - & 51.13 & 34.05 \\
\hline MM99/0067 & 37.06 & 40.59 & 44.14 & 43.39 & 35.97 \\
\hline MM99/0072 & 51.98 & 50.27 & 62.18 & 55.18 & 34.58 \\
\hline MM99/4884 & 54.94 & 45.15 & 52.84 & 50.01 & 31.24 \\
\hline Nyar AICAD & 41.35 & 24.94 & 48.17 & 48.01 & 20.68 \\
\hline Nyar JICA & 48.88 & 42.68 & 44.41 & 48.74 & 36.96 \\
\hline Nyar Maseno & 26.63 & 45.86 & 50.74 & 11.59 & 34.37 \\
\hline NyaTanga & 41.59 & 44.0 & 53.19 & 51.83 & 35.11 \\
\hline ObaroDak & 42.65 & 33.52 & 53.43 & 50.78 & 41.42 \\
\hline Oduwo & 50.76 & 50.36 & 58.06 & 36.37 & - \\
\hline Okonyo Welo & 43.19 & 46.46 & 52.3 & 51.51 & 38.51 \\
\hline Olomba & 44.36 & 41.84 & 53.39 & - & 33.26 \\
\hline Rao Onyoni & 47.43 & 46.96 & 59.65 & 52.02 & 27.94 \\
\hline Selele Rabuor & 40.96 & 48.45 & 60.51 & 58.41 & 41.96 \\
\hline $\operatorname{LSD}(0.05)$ & 2.72 & 4.78 & 3.64 & 6.23 & 6.77 \\
\hline
\end{tabular}

The (-) in the columns represent no data for those varieties for the respective parameter since those varieties failed to produce recordable yields in the evaluation at respective sites

Dry matter. Cassava dry matter contents from the different varieties varied across varieties and sites (Table 4); ranging from 26.63 - 54.94\% at Solai I site; $24.94-50.36 \%$ at Soali II site; $44.14-60.51 \%$ at Solai III site; $11.59-58.41 \%$ at Lare and $20.68-42.8 \%$ at Subukia. Godfrey et al. (2012) also observed wide genotypic effects on dry matter content of cassava varieties. In the current study, except for a few occurrences, the cultivars tested recorded dry matter contents of more than $30 \%$ in all sites. This was in conformity with the expected range of $30-40 \%$ recommended by breeders for processing (Kawano, 2003). The highest dry matter content recorded in the present study was $60.51 \%$ from variety Selele rabuor at Solai III site. Dry matter content has been identified as 
a primary factor that determines adoption of new cassava varieties by farmers, and also the market value of harvested roots (Okechukwu and Dixon, 2008). High dry matter content is a preferred trait as it is directly correlated with high starch content, an important factor in selecting cassava for industrial applications (Safo-Kantanka and Owusu-Nipa, 1992).

\section{CONCLUSION}

This study has revealed that several adaptable varieties with high yields and suitable food and processing attributes can be selected for the specific locations in the ASAL regions of western Kenya. Based on yield and cyanide levels (farmer sensory taste) the following cassava varieties were selected for respective study sites: five varieties (MM96/0067, NyaTanga, Adhiambo Lera, KME-1, and MH95/0183) for the Subukia area; four varieties (Nyar AICAD, Nyar Maseno, NyaTanga, and MM96/2480) for Lare and five varieties (KME-1, Nyar AICAD, Adhiambo Lera, Karembo and Obaro dak)for the Solai area, respectively. Inconsistence was found in the correlation between cyanide levels and sensory scores, confirming that cassava consumption safety is not exclusivelya genetic factor.

\section{ACKNOWLEDGEMENT}

The authors are grateful to the MasterCard Foundation and Regional Universities Forum for Capacity Building in Agriculture (RUFORUM) for funding research and publication cost through the Transforming African Agricultural Universities to meaningfully contribute to Africa's growth and development (TAGDev) Program.

\section{REFERENCES}

Association of Official Analytical Chemists (AOAC). 1990. Official Method of Analysis. $15^{\text {th }}$ Edn. Washington D.C., USA.
Association of Official Analytical Chemists (AOAC). 2006. Official Methods of Analysis. 18 ${ }^{\text {th }}$ Edition. Gaithersburg, Maryland, USA.

Bokanga, M. 1994. Processing of cassava leaves for human consumption. Acta Horticulturae 375:203-208.

Bradbury, J.H. and Holloway, W.D. 1988. Chemistry of tropical root crops: Significance for nutrition and agriculture in the Pacific. Monograph No. 6. Australian Centre for International Agricultural Research, Canberra, Australia. 201pp.

Cardoso, A.P., Mirione, E., Ernesto, M., Massaza, F., Cliff, J., Haque, M.R. and Bradbury, J.H. 2005. Processing of cassava roots to remove cyanogens. Journal of Food Composition and Analysis 18:451460.

Centro Internacional de agricultura Tropical (CIAT). 1989. Stretching the water-stress limits of cassava. Cali, Colombia. 98pp.

Centro Internacionaldeagricultura Tropical (CIAT). 2007. Improved cassava for the developing world. Annual report. 39pp.

Chu, J. 2015. Cyanides and food safety. Food safety focus. Incident in focus: Centre for Food Safety, Hong Kong. 6pp.

Dixon, A.G.O., Asiedu, R. and Hahn, S.K. 1991. Genotypic stability and adaptability: Analytical methods and implications for cassava breeding for low input Agriculture. In: Proceedings of the $9^{\text {th }}$ Symposium of the International Society for Tropical Root Crops, October 20-26, Accra, Ghana. pp. 130-137.

Food and Agriculture Organization of the United Nations (FAO). 2007. June 2003 Cassava market assessment. www.fao.org /docrep/019/i 3473e/i3473 e.pdf. Accessed on 15 May 2020.

Food and Agriculture Organization of the United Nations (FAO). 2013. Save and grow: Cassava, a guide to sustainable production intensification. E-ISBN 978-925-107642-2. 
Fukuda, W.M.G., Guevara, C.L., Kawuki, R.and Ferguson. M.E.1998. Selected morphological and agronomic descriptors for the characterization of cassava. International Institute of Tropical Agriculture (IITA), Ibadan, Nigeria. 19pp.

Gitebo, D.N., Banea-Mayabu, J.P., Matadi, R.N., Tylleskar, T., Gebre-Medhin, M. and Rosling, H. 2009. Geographical and seasonal association between linamarin and cyanide exposure from cassava and the upper motor neuron disease Konzo in DRC. In: Cassava Cyanide Disease and Neurolathyrism Network (CCDN) News, Issue 14.

Godfrey, A.I., Ezekiel, U.U. and Donatus, F.U. 2012. Selection criteria for stem and tuber yield in cassava (Manihot esculenta Crantz). AmericanJournal of Plant Science 8:1120-1124.

Jaetzold, R., Hornetz, B., Shisanya, C.A. and Schmidt, H. 2010. Farm Management Handbook of Kenya- Vol. I-IV (Western, Central, Eastern, Nyanza, Southern Rift Valley, Northern Rift Valley, Coast). Ministry of Agriculture in Cooperation with German Agency for Technical Cooperation, Nairobi, Kenya.

Kawano, K. 2003. Thirty years of cassava breeding for productivity: Biological and social factors for success. Crop Science 43:1325-1335.

Ndung'u, J.N., Wachira, F.N., Kinyua, M.G., Lelgut, D.K., Okwaro, H., Njau, P. and Obiero, H. 2012. Influence of the environment on cassava quality traits in central Rift Valley of Kenya. American Journal of Plant Science 3:1504-1512.
Oke, O.L. 1969. The role of hydrocyanic acid in nutrition. World Review of Nutrition and Dietetics 11:170-98.

Okechukwu, R.U. and Dixon, G.O. 2008. Genetic gains from 30 years of cassava breeding in Nigeria for storage root yield and disease resistance in elite cassava genotypes. Journal of Crop Improvement 22:181-208.

Raji, AA., LLadeinde, T.A.O. and Dixon, G.O. 2007. Agronomic traits and tuber quality attributes of farmer grown cassava in landraces in Nigeria. Journal of Tropical Agriculture 45(1-2):9-13.

Safo-Kantanka, O. and Owusu-Nipa, J. 1992. Cassava varietal screening for cooking quality: Relationship between dry matter, starch content, mealiness and certain microscopic observations of the raw and cooked tuber. Journal of the Science of Food and Agriculture 60:90-104.

Srihawong, W., Kongsil, P., Petchpoung, K. and Sarobol, E.D. 2015. Effect of genotype, age and soil moisture on cyanogenic glycosides content and root yield in cassava (Manihot esculenta Crantz). Kasetsart Journal (Natural Science) 49:844-855.

Tan, S.L. 1995. Factors affecting cyanide content in cassava (Manihot esculenta Crantz). Journal of Tropical Agriculture and Food Science 23(2):121-131.

World Bank. 2018. Kenya Agricultural Productivity Program (KAPP I AND II). Independent Evaluation Group, Project Performance Assessment Report 133838. Washington, DC: World Bank. 